\title{
THE EFFECT OF CAPITAL ADEQUACY AND ASSET QUALITY ON THE VALUE OF THE BANK AN APPLIED STUDY ON A SAMPLE OF IRAQI BANKS LISTED ON THE IRAQ STOCK EXCHANGE
}

\author{
Sura Dhaygham Hazim, Dr. Hanadi Seker Makttoof \\ University of Baghdad / College of Administration and Economics
}

DOI: $10.37648 /$ ijrssh.v10i02.014

Received:08 ${ }^{\text {th }}$ January, 2020; Accepted:02nd February, 2020; Published: $26^{\text {th }}$ February, 2020

\begin{abstract}
As the banking sector is a strong influence on the country's economic growth,The solid financial well-being of any bank does not mean only a guarantee for its investors, It is also important for both owners and workers and for the economy in all its joints.The elements of capital adequacy and quality of assets are important to the functioning of the banking business.In this study, the research sample included four private banks. Quarterly data were used for the period (2011 - 2018).Moreover, data is also collected from articles, papers, the World Wide Web (the Internet) and specialized international journals.In this research, an effort was made to try to find out the effect of (the ratio of the capital owned to deposits on the value of the bank), (the ratio of the capital owned to the assets to the value of the bank), (the ratio of investments to assets on the value of the bank), and (the ratio Loans to assets on the value of the bank). The results showed that there is a discrepancy in the effect of these ratios on the value of the bank for those banks in the research sample.
\end{abstract}

Key words: capital adequacy, quality of assets, value of the bank.

\section{INTRODUCTION}

The prosperity of the country depends on multiple ingredients.Each of these ingredients has an important pillar that is the heart of life.As the banking sector is the pillar of the economic development of any country with a free competing economy,it is the backbone that manages the financial movement and directs it towards the streams generating financial returns on the bank and the country's economic system at the same time.The value of the bank is important for both the bank's management and investors, because increasing interest in the value of the bank is the main focus of both the bank and investors alike.Financial ratios contribute to providing summary information about the financial situation and the activities of the bank and obtaining useful information that can be analyzed and evaluated for the performance of the bank, And help to reach the value of the bank. Often, shareholders in the management of the bank seek to increase the number of shares that lead to an increase in the value of the bank. Where some believe that the value of the bank depends on the private part of the shares owned by the management,the ownership of the administrative shares 
has a functional relationship with the value of the bank. Also, this would maximize the community's wealth, as shareholders are part of the community.

\section{METHODOLOGY}

\section{First: a problem}

The research problem enables to know the extent of the financial power that the Iraqi banks possess the research sample with regard to capital adequacy ratios and asset quality ratios, And the impact of each of them on the value of the bank in light of all the crises and difficulties that the country witnessed, whether globally or internally. For the time period from 2011 to 2018, the research problem can be formulated in the following two questions:

1- Is there a relationship of influence of indicators of capital adequacy ratios on the value of the bank and at the level of banks?

2- Is there a relationship of impact of indicators of asset quality ratios on the value of the bank and at the level of banks?

\section{Second: Importance}

The importance of the research lies in identifying the strengths that Iraqi banks possess in order to enhance their position in the private banking sector, which supports the confidence of investors and depositors, and in what achieves its support for the national economy.

\section{Third: objective}

The research aims to study the effect of capital adequacy ratios and the quality of assets for Iraqi banks during the period discussed (from 2011 to 2018), and the impact of each of them on the value of the bank.

\section{Fourth: A hypothesis}

1. There is no statistically significant effect of the ratio of the capital owned to the deposit on the value of the bank.

2. There is no statistically significant effect of the ratio of the capital owned to the assets on the value of the bank.

3. There is no statistically significant effect of the ratio of investments to assets index on the value of the bank.

4. There is no statistically significant effect of the loan-to-asset ratio index on the value of the bank.

\section{LITERATURE REVIEW}

First: Capital adequacy

Every financial institution has strong bonds with an important term for its operating system, Capital adequacy ratio; Because it works to help banks absorb any unexpected shocks, So that it can protect the bank's operations effectively and completely to avoid failure by absorbing losses. The ratio of capital adequacy assumes that the level of capital is adjusted in an ad hoc manner with the time when an increase in each of the total operating expenses is expected, along with the withdrawal needs (Abusharba et al, 2013: 161). Capital adequacy also indicates that the financial institution will continue to fulfill all of its obligations, As this ratio is used to determine the ability of the financial institution to meet its obligations in terms of time, Also, in terms of risk, its ability to cope with it, such as credit risks, operational risks, etc. (Nzloki, 2011: 21). Capital adequacy was interpreted as one of the most important indicators of the extent of the financial recovery of the banking sector. As it indicates the ability of banks to be flexible and deal with capital in a manner that is appropriate to the nature, degree or level of all types of risks, Likewise, the ability of the bank management to identify those risks and monitor them or put them under observation and work to control them (Suresh and Paul,64: 2010). Sufficient capital provides an opportunity to obtain appropriate standards in any business, because it stimulates work and performance efforts in rearranging the capital structure (Ezike \& M.O, 2013: 148). The capital adequacy ratio was measured through the following measures:

1- Owned capital to deposits: The ratio measures the extent of the bank's ability to cover deposits from the owners' capital, In the sense of returning their customers' deposits at any emergency that leads to depositors withdrawing their deposits or a large part of them, as a high percentage represents a safety source for depositors, As this percentage is based on controlling the risks resulting from the increase in total deposits from a certain percentage in the capital (Al-Mikhlafi, 16:2004).

2- The ratio of the capital owned to the assets: The importance of this ratio lies in the fact that it relates the capital owned to the total assets to meet any unexpected losses, It also clarifies the bank's efficiency in operating the available financial resources, and its efficiency in operating the 
financial capabilities in performing all banking services, the return of which is represented in the commissions and benefits accrued (Hashim \& Muhmad, 2015: 116).

\section{Second: Asset quality}

From the fortieth decade until the fiftieth decade of the last century, in light of the intense competition and scarcity of financial resources, And the invasion of technology, the entry of computers and their development, information technology and systems, The focus started and highlighting the assets and investing them in the optimal way, which would benefit the bank.If the assets are considered one of the pillars of the bank's stability,its success depends on its quality and proper management (Tom, 2012: 17) (Ombaba, 2013: 155).The term asset quality refers to the overall risk associated with the various assets that the bank owns, As banks determine the size of their assets that may be exposed to financial risks, Estimating the amount of provisions to address the potential losses that you must incur (Baral 2005: 44) (Abata, 2014: 39) (Ishaq, 2016: 25).The correlation between asset quality and capital adequacy has an impact on the performance of the bank,because the quality of the assets measures the financial efficiency of the banks. While the capital adequacy movement axis measures the level of continuous interest in the banks' capital, which makes managing the bank's financial efficiency at the required level. In practice, the decline in the quality of assets affects further improving the capital adequacy position in order to provide the required bank protection against risks.This prompted the move to a better position (Pastory \& Mutaju, 2013: 179).Asset quality ratios are measured through the following measures:

1- Investments to assets: This ratio indicates the extent to which the bank's assets are used in investments.It is used as a tool to measure the percentage of total assets held in favor of investments.The high ratio indicates the conservative policy of the bank to provide protection for its investments against bad loans (K.S. et al, 2018: 1579).

2- Loans to assets: This ratio is one of the indicators for investing money in the bank, it measures the adequacy of investment and the employment of funds available to the bank. This high percentage indicates good exploitation of loans.But it reflects its significant increase in the increase in loans that the bank will have to face in the event that it is not paid by borrowers on schedule.Hence, its rise is negative for the bank's liquidity level (Sathyamoorthi et al, 2017: 149).

\section{Third: The value of the bank}

Since the 1990s, increased interest in the value of the bank, especially in European banks, and after the rapid developments in the financial and banking markets.Increased interest in the value of the bank, especially in European banks, and after the rapid developments in the financial and banking markets.This prompted stakeholders and stakeholders to take a new approach to maintaining that value (Fiordelisi, 2002: 1).As is well known,Profit organizations in general,And banks in particular, keep the financial goal in mind.Therefore, banks have worked hard to increase their market value (Gill \&obradovic, 2012: 3). The bank's employees and investors also aim to increase their assets, either, from achieving various capital gains.Managers work for the best interests of shareholders, and this happens when shareholder returns are increased (Dewet \& Mpinda, 2013:1451),In addition, these returns consist of capital gains in the form of share price increases (Alim al et, 2014: 20) (Tahir \& Raja, 2014: 24). Or by dividends, meaning that the policy of optimum dividends increases the share price of the bank,this leads to an increase in shareholder wealth,thus ensuring rapid economic growth (Ofori, 2017: 294).The value of the bank was measured using the Tobin's Q equation established by Kapoor and his colleagues. This measure is used in banks more than in industrial companies (Caprio et al, 2007: 591):

$$
\text { Tobin's } Q=\frac{\text { (The ratio of the market value of equity }+ \text { the book value of liabilities) }}{\text { the book value of assets }}
$$


Noting that whenever the value of TQ exceeds (1) this indicates good performance of the bank, high profitability and an increase in the value of the bank, meaning that the market value of the bank is higher than the value of assets, which means that there are better opportunities for investment and an indication of good management performance, and in If the value of TQ is lower than (1) then this is that the value of the assets is higher than the market value of the bank, i.e. the bank is undervalued (Ali, 2014: 309).

\section{ANALYSIS AND DISCUSSION}

This section reviews the most important findings of the researcher from his analysis of research variables in all its indicators to show their impact on the value of the bank, for the banks listed in the Iraq Stock Exchange.As it tries to reach what has been assumed in the research methodology, and then to show the impact of each of these indicators on the value of the bank at the level of the research sample banks.

\section{A. Assuming testing of the investment bank}

Table (1) shows the regression analysis between all indicators of capital adequacy, quality of assets and the value of the bank to the investment bank:

Table (1) ANOVA analysis of the investment bank variance

\begin{tabular}{|l|l|l|l|}
\hline Financial indicators & $\mathbf{R}^{2}$ & $\mathbf{F}$ & Sig. \\
\hline The ratio of owned capital to deposits (X11) & $\mathbf{. 7 1 0}$ & $\mathbf{7 3 . 3 2 8}$ & $\mathbf{. 0 0 0}$ \\
\hline The ratio of the owned capital to the assets (X12) & $\mathbf{. 5 7 9}$ & $\mathbf{4 1 . 2 7 8}$ & $\mathbf{. 0 0 0}$ \\
\hline The ratio of investments to assets (X13) & $\mathbf{. 7 9 9}$ & $\mathbf{1 1 9 . 3 3 5}$ & $\mathbf{. 0 0 0}$ \\
\hline The ratio of loans to assets (X14) & $\mathbf{. 6 5 9}$ & $\mathbf{5 8 . 0 7 2}$ & $\mathbf{. 0 0 0}$ \\
\hline
\end{tabular}

Source: Preparing the two researchers based on the results of the SPSS 24 program

Found from the ANOVA variance analysis table for the investment bank, as follows:

1- There is a strong influence that exceeds $60 \%$ of the indicators (X14), (X11), (X13) with the bank value, as the coefficient of determination for them reached $\mathrm{R}^{2}$ respectively $(0.659),(0.710),(0.799)$.

2- There was an effect of about $50 \%$ of the index (X12) with the value of the bank, as it reached $\mathrm{R}^{2}(0.579)$.

3- Statistically significant according to the $\mathrm{F}$ test because the calculated value of $\mathrm{F}$ for all indicators was greater than the value of the scheduled F (4.171) at the significance level 0.05, which means rejecting the assumptions (first, second, third and fourth) with acceptance of the alternative hypothesis of the existence of the effect of these indicators and the value of the bank.

Table (2) also shows the simple regression equations for the investment bank and the amount of change for each indicator of the bank's value:

Table (2) simple regression equations for the investment bank

\begin{tabular}{|c|l|}
\hline Simple regression equations & The amount of change \\
\hline$Y=1.169-0.376 X 11$ & A change in one unit of X11 will change a $Y$ of $(-0.376)$. \\
\hline$Y=1.367-1.226 X 12$ & A change by one unit of X12 will cause a change in $Y$ by $(-1.226)$. \\
\hline$Y=0.955-5.896 X 13$ & A change by one unit of X13 will cause a change in $Y$ by $(-5.896)$. \\
\hline$Y=0.583+0.833 X 14$ & A change by one unit of X14 will cause a change in $Y$ by $(0.833)$. \\
\hline
\end{tabular}

Source: Preparing the two researchers based on the results of the SPSS 24 program

\section{B. Assumptions testing of Ashur Bank.}

Table (3) shows the regression analysis between all indicators of capital adequacy, quality of assets and bank value of Ashur Bank: 
Table (3) ANOVA variance analysis for Ashur bank

\begin{tabular}{|l|l|l|l|}
\hline Financial indicators & $\mathbf{R}^{2}$ & $\mathbf{F}$ & Sig. \\
\hline The ratio of owned capital to deposits $(\mathbf{X 2 1})$ & $\mathbf{. 0 8 4}$ & $\mathbf{2 . 7 4 5}$ & $\mathbf{. 1 0 8}$ \\
\hline The ratio of the owned capital to the assets $(\mathbf{X 2 2})$ & .154 & $\mathbf{5 . 4 4 1}$ & $\mathbf{. 0 2 7}$ \\
\hline The ratio of investments to assets $(X 23)$ & .173 & $\mathbf{6 . 2 7 7}$ & $\mathbf{. 0 1 8}$ \\
\hline The ratio of loans to assets $(X 24)$ & $\mathbf{. 8 2 4}$ & $\mathbf{1 4 0 . 6 5 5}$ & $\mathbf{. 0 0 0}$ \\
\hline
\end{tabular}

Source: Preparing the two researchers based on the results of the SPSS 24 program

The ANOVA contrast analysis table for Ashur Bank comes as follows:

1- It was found that there was a strong influence in excess of $60 \%$ of the index (X24), with the value of the bank, as the coefficient of determination was $\mathrm{R}^{2}$, respectively $(0.824)$.

2- There is a weak effect below the $40 \%$ for indicators (X22) and (X23) with the value of the bank, as it reached $\mathrm{R}^{2}$, respectively (0.154) and (0.173).

3- There is no effect of the index (X21), with the bank value and non-statistically significant according to the F test because of the calculated value of $F(0.24)$ less than the tabular value of $F(4.171)$ at the level of significance 0.05 , which means accepting the first null hypothesis and rejecting the alternative hypothesis due to the lack of Effect of this indicator and the bank value of Ashur Bank.

4- Statistical indicator according to the F test obtained for all indicators except for the indicator (X21) greater than the tabular value of $\mathrm{F}$ (4.171) at a level of 0.05 annually, which means rejecting the assumptions (second, third and fourth), while accepting the alternative hypothesis of the existence of these indicators And the value of the bank.

Table (4) gives the simple regression equations for Ashur Bank and the amount of change for each indicator of the bank's value:

Table (4) simple regression equations for Ashur bank

\begin{tabular}{|l|l|}
\hline Simple regression equations & The amount of change \\
\hline $\mathrm{Y}=1.202-0.916 \mathrm{X22}$ & A change by one unit of $\mathrm{X} 22$ will cause a change in $\mathrm{Y}$ by $(-0.916)$. \\
\hline $\mathrm{Y}=\mathbf{0 . 5 8 5}+\mathbf{4 . 3 6 2} \mathrm{X23}$ & A change by one unit of $\mathrm{X} 23$ will cause a change in $\mathrm{Y}$ by $(4.362)$. \\
\hline$Y=0.511+1.195 X 24$ & A change by one unit of $X 24$ will result in a change in $\mathrm{Y}$ of $(1.195)$. \\
\hline
\end{tabular}

Source: Prepared by the two researchers, based on the results of the SPSS 24 program

\section{Hypotheses testing for a Credit Bank of Iraq}

Table (5) shows the regression analysis between all indicators of the capital adequacy, the quality of the assets and the value of the bank to the Credit Bank of Iraq

Table (5) ANOVA variance analysis for the Credit Bank of Iraq

\begin{tabular}{|l|l|l|l|}
\hline Financial indicators & $\mathbf{R}^{2}$ & $\mathrm{~F}$ & Sig. \\
\hline The ratio of owned capital to deposits $(\mathbf{X 3 1})$ & $\mathbf{. 4 5 3}$ & $\mathbf{2 4 . 8 2 7}$ & $\mathbf{. 0 0 0}$ \\
\hline The ratio of the owned capital to the assets $(\mathbf{X 3 2})$ & $\mathbf{. 2 4 6}$ & $\mathbf{9 . 7 7 8}$ & $\mathbf{. 0 0 4}$ \\
\hline The ratio of investments to assets $(X 33)$ & $\mathbf{. 0 5 4}$ & $\mathbf{1 . 7 0 7}$ &. $\mathbf{2 0 1}$ \\
\hline The ratio of loans to assets $(X 34)$ & $\mathbf{. 5 3 0}$ & $\mathbf{3 3 . 7 9 6}$ & $\mathbf{. 0 0 0}$ \\
\hline
\end{tabular}

Source: Prepared by the two researchers, based on the results of the SPSS 24 program 
The ANOVA Table of Contrast Analysis for the Credit Bank of Iraq shows the following:

1- There is an effect of about $50 \%$ for the two indicators (X34) (X31) with the value of the bank, as it reached $\mathrm{R}^{2}$ respectively (0.530), (0.453).

2- There is a weak effect below the $40 \%$ of the index (X32) with the value of the bank, as it reached $R^{2}(0.246)$.

3- There is no effect of the index (X33) with the bank value and non-statistically significant according to the F test because of the calculated value of F (0.054) is less than the value of the tabular F (4.171) at the level of significance 0.05 , which means accepting the null hypothesis (the third) and rejecting the alternative hypothesis because there is no effect For those two indicators and the bank's value for the Credit Bank of Iraq.

4- Statistical indicator according to the F test, as the calculated F value for all indicators except for the indicator (X33) is greater than the tabular value of $\mathrm{F}$ (4.171) at the significance level 0.05, which means the sub-sign-assumptions (first, second and fourth) is accepted, while accepting alternative hypotheses To influence these indicators and the value of the bank to the Credit Bank of Iraq.

Table (6) shows the simple regression equations for the Credit Bank of Iraq and the amount of change for each indicator of the bank's value:

Table (6) Simple Regression Equations for a Credit Bank of Iraq

\begin{tabular}{|c|l|}
\hline Simple regression equations & The amount of change \\
\hline$Y=1.534-0.462 X 31$ & A change by one unit of X31 will cause a change in $Y$ by $(0.462-)$. \\
\hline$Y=1.688-1.628 X 32$ & A change by one unit of X32 will cause a change in $Y$ by $(1.628-)$. \\
\hline$Y=0.771+37.913 X 34$ & A change by one unit of X34 will cause a change in $Y$ by $(37.913)$. \\
\hline
\end{tabular}

Source: Preparing the two researchers based on the results of the SPSS 24 program

\section{Hypotheses testing for the Iraqi Commercial Bank.}

Table (7) shows the regression analysis between all indicators of capital adequacy, quality of assets and the value of the bank for the Iraqi Commercial Bank:

Table (7) ANOVA variance analysis for the

\begin{tabular}{|l|l|l|l|}
\hline Financial indicators & $\mathbf{R}^{2}$ & $\mathbf{F}$ & Sig. \\
\hline The ratio of owned capital to deposits $(\mathbf{X 4 1})$ & .383 & $\mathbf{1 8 . 6 1 7}$ & $\mathbf{. 0 0 0}$ \\
\hline The ratio of the owned capital to the assets $(\mathbf{X 4 2})$ & .495 & $\mathbf{2 9 . 4 3 4}$ & $\mathbf{. 0 0 0}$ \\
\hline The ratio of investments to assets $(\mathbf{X} 4)$ & .034 & $\mathbf{1 . 0 6 9}$ &. $\mathbf{3 0 9}$ \\
\hline The ratio of loans to assets $(X 44)$ & .339 & $\mathbf{1 5 . 4 1 2}$ & $\mathbf{. 0 0 0}$ \\
\hline
\end{tabular}

Source: Preparing the two researchers based on the results of the SPSS 24 program

We obtain from the ANOVA contrast analysis table for the Iraqi Commercial Bank, as follows:

1- There is an effect around $50 \%$ of the index (X42), with the bank value, as it reached $\mathrm{R}^{2}(0.495)$.

2- There is a weak effect below the $40 \%$ of the two indicators (X41), (X44) with the value of the bank, as it reached $\mathrm{R}^{2}$, respectively (0.383) and (0.339).

3- There is no effect of the index (X43) with the bank value and non-statistically significant according to the $\mathrm{F}$ test because of the calculated value of F respectively (1.069) which was less than the value of the tabular F (4.171) at the level of significance 0.05 , which means accepting the null hypotheses (third) and rejecting the alternative hypothesis This is because there is no effect of that indicator and the bank's value on the Iraqi commercial bank.

4- statistical indication according to the F test, as the calculated F value for all indicators except for the index (X43) is greater than the tabular value of $\mathrm{F}(4.171)$ at the level of significance 0.05 , which means rejecting the assumptions (first, second, and fourth), while accepting alternative hypotheses because there is an effect of these Indicators and the value of the bank to the Iraqi commercial bank. 
Table (8) presents the simple regression equations for Iraqi Commercial Bank and the amount of change for each indicator of the bank's value:

Table (8) simple regression equations for the Iraqi Commercial Bank

\begin{tabular}{|c|l|}
\hline Simple regression equations & The amount of change \\
\hline$Y=1.100-0.165 X 41$ & A change by one unit of X41 will cause a change in $Y$ by $(-0.165)$. \\
\hline$Y=1.692-1.570 X 42$ & A change by one unit of X42 will cause a change in $Y$ by $(-1.570)$. \\
\hline$Y=0.622-7.110 X 44$ & A change by one unit of $X 44$ will cause a change in $Y$ by $(-7.110)$. \\
\hline
\end{tabular}

Source: Preparing the two researchers based on the results of the SPSS 24 program

\section{CONCLUSIONS AND RECOMMENDATIONS}

\section{First: the conclusions}

The analysis and discussion of research variables showed that the ratio of capital owned to deposits in banks to the research sample was very differentiated impact on the value of the bank, as its effect was strong with the bank (investment, credit) as a result of the interest of those banks and taking into account control of the risks resulting from increasing the total deposits on Owned capital, while the effect of this ratio on the value of the bank was weak with the commercial bank, while there was no effect on the value of the bank with the Ashur bank.

It was also found from the analysis and discussion of research variables that the ratio of the capital owned to the assets in the banks of the research sample was their mixed effect on the value of the bank, as the effect of this ratio on the value of the bank with the two banks (investment, commercial) was very strong, and this indicates the interest of those banks in Operating available financial resources. While its impact was weak on the value of the bank with the two banks (Ashur, credit).

It was clear from the analysis and discussion of research variables that the ratio of investments to assets in the banks of the research sample was very different to the bank's value, because this ratio had an impact on the bank's value with the bank (the investment), which indicates the bank's interest in investing its asset investments .While its effect was weak with Ashur Bank, while there was no effect on this percentage on the bank's value with both banks (commercial credit).

It was found from the analysis and discussion of research variables, that the ratio of loans to assets in the banks of the research sample were different in their impact on the value of the bank, as the effect of this ratio on the value of the bank was strong with banks (investment, credit and Ashur), and this indicates the interest of those banks in operating Financial resources available in loans. Whereas, the effect of this percentage on the value of the bank was weak with a (commercial) bank.

\section{Second: Recommendations}

Banks should not accept deposits in an amount that exceeds the amount owned by the capital, otherwise they will enter into what is called a "spiral tunnel", which places them in a cycle without a decision.

Careful monitoring of the ratio of capital adequacy to assets gives banking protection to follow up the size of the assets increase, and to care for cases of excess in that ratio because it will negatively affect profitability and liquidity.

The capital that is owned is considered the bulwark of the bank. It is the bank's strength and its ability to work and choose the most appropriate to carry out its activities. Therefore, the banks administration must maximize that power by entering shareholders who have the ability to support the bank financially.

The banks investment in their assets within its investment policy, ensuring that they exploit their assets in a continuous manner, and this is also a selfgenerating system of its revenue system.

\section{SOURCES}

1. Abata, Matthew Adeolu(2014), Asset Quality and Bank Performance: A Study of Commercial Banks in Nigeria, Journal of Finance and Accounting, Volume(5), Number (18), pp:39-44.

2. Abusharba, M. T., Triyuwono, I., Ismail, M., \& Rahman, A. F. (2013), Determinants of Capital Adequacy Ratio (CAR) in Indonesian Islamic Commercial Banks, Global Review of Accounting and finance, 4(1), pp:139-170.

3. Ali Jeeran Abed, Ali (2014), The Effect of Stock Liquidity on Firm Value Evidence from Iraqi Stock Exchange, Al-Muthanna Journal of 
Administrative and Economic Sciences, Volume (4), Issue (9), pp. Pp. - 322-305

4. Alim, Wajid \& Ali, Arshad \& Ali, Nazim\& Khattak, Bakhtiar Khan \& Qureshi, Mohammad Imran (2014), Impact of Dividend Policy on Shareholder Wealth in Pakistan (Evidence Textile Industry Perspective), Gomal University Journal of Research, 30,(1), pp:18-31.

5. Al-Mikhlafi, Abdul Aziz Muhammad Ahmed (2004), Capital Adequacy Analysis and its Impact on the International Equation (An Applied Study in a Sample of Yemeni Banks), Unpublished PhD thesis, College of Administration and Economics, University of Baghdad.

6. Baral, K. J. (2005), Health check-up of commercial banks in the framework of CAMEL: A case study of joint venture banks in Nepal, Journal of Nepalese Business Studies, 2(1), 41-55.

7. Caprio, Gerard \& Laeven, Luc \& Levine, Ross, (2007), Governance and Bank Valuation, Journal of Financial International, (16), pp:584-617

8. De Wet, Johannes de\&Mpinda , Mvita (2013), The Impact Of Dividend Payments On Shareholders' Wealth: Evidence From The Vector Error Correction Model, International Business \& Economics Research Journal, Volume 12,pp: $\underline{1451-1466}$

9. Ezike, J. E., \& MO, O. (2013). Capital Adequacy Standards, Basle Accord and Bank Performance: the Nigerian Experience (A Case Study of Selected Banks in Nigeria), Asian Economic and Financial Review, 3(2), 146.

10. Fiordelisi, F. (2002), Shareholder Value and the Clash in Performance Measurement: Are Banks Special, In Actes du XI International" Tor Vegata" Conference on Banking and Finance.

11. Hashim, Hafiza Aisha and Muhmad, Siti Nuruin (2015), Using The CAMEL Framework In Assessing Bank Performance in Malaysia, International Journal of Economics. Management and Accounting 23, no.1 : 109-127

12. Ishaq, A., Karim, A., Zaheer, A., \& Ahmed, S. (2016), Evaluating Performance of Commercial Banks in Pakistan:'An Application of Camel Model', Available at SSRN 2716691.

13. K. S., Manoj Narayanan\& Thomas, Asha\& Abraham ,Chandapillai M.(2018),Performance
Evaluation of Public Sector Banks Based on CAMEL Methodology,International Journal of Engineering Technology Science and Research, Volume( 5), Issue (1 ),pp:1575-1585.

14. Nzioki,Suka Justus (2011),The Impact of Capital Adequacy on the Financial Performance of Commercial Banks Quoted at the Nairobi Stock Exchange, Degree of Masters of BusinessAdministration-School of Business, University of Nairobi

15. Obradovich, J., \& Gill, A. (2013), The Impact of Corporate Governance and Financial Leverage on the Value of American Firms, Issue 91

16. Ofori-Sasu, D. Abor, J.Y., \& Osei, A. K. (2017), Dividend policy and shareholders' value: evidence from listed companies in Ghana, African Development Review, 29(2), 293-304.

17. Ombaba, K. B. M. (2013), Assessing the Factors Contributing to Non-Performance Loans in Kenyan Banks,European Journal of Business and Management ,Volume (5), Number (32),pp:155- 163.

18. Pastory,Dickson \& Mutaju,Marobhe (2013), The Influence of Capital Adequacy on Asset Quality Position of Banks in Tanzania, International Journal of Economics and Finance; Volume(5) Number(2),pp:179-194.

19. Sathyamoorthi, C. R. \& Mapharing, Mogotsinyana, \& Ndzinge, Shabane (2017), Performance Evaluation of Listed Commercial Banks in Botswania: The CAMEL Model, Archives Business Research, Volume (5), Number 10, pp :142-159.

20. Suresh, P. \& Paul, J. (2010), Management of Banking and Financial services, Pearson India.

21. Tahir, Asma \& Raja, NainTaraSarfarz(2014 ),Impact of Dividend Policy on Shareholder Wealth, Journal of Business and Management, Volume (16), Issue (1), PP: 24-33.

22. Tom, K. A. (2012), Effects of CAMEL variables on bank efficiency: A panel analysis of Kenyan commercial banks, $\underline{\text { Unpublished MBA Research }}$ project. University of Nairobi. 